\title{
Arbuscular mycorrhizal fungal colonization in three different age groups of rubber plantations in Tripura, North-East India
}

\author{
Chakraborty $\mathrm{K}^{1}$, Sinha $\mathrm{S}^{2}$, Debnath $\mathrm{A}^{1}$, Roy Das $\mathrm{A}^{2}$, Saha $\mathrm{AK}^{2}$ and Das $\mathbf{P}^{1 *}$ \\ ${ }^{1}$ Microbiology Laboratory, Department of Botany, Tripura University, Suryamaninagar-799 022, Tripura, India \\ ${ }^{2}$ Mycology and Plant Pathology Laboratory, Department of Botany, Tripura University, Suryamaninagar-799 022 , \\ Tripura, India
}

Chakraborty K, Sinha S, Debnath A, Roy Das A, Saha AK, Das P 2016 - Arbuscular mycorrhizal fungal colonization in three different age groups of rubber plantations in Tripura, North-East India. Plant Pathology and Quarantine 6(2), 122-131, Doi 10.5943/ppq/6/2/2

\begin{abstract}
Soil chemical properties, arbuscular mycorrhizal (AM) fungal colonization, AM fungal morphology in root and diversity of AM fungi in rubber plantations of three different age groups of 5, 10 and 30 years old of Tripura, North-East India were investigated. The result exhibited positive correlation $(p<0.05)$ between AM colonization and spore density with available nitrogen. There was a positive significant correlation between AM colonization with spore density. AM fungal colonization was significantly higher in 5 and 10 than 30 years old plantation. Arum type of AM fungal morphology was observed in the root. A total of 12 morphotypes were isolated belonging to the genera Acaulospora, Ambispora and Glomus. Out of which 5, 9 and 9 AM fungal species were isolated from the rubber plantations of 30,10 and 5 years old, respectively. Shannon diversity index was highest in 5 years old and lowest in 30 years old plantation. Evenness was highest in 30 years old and lowest in 10 years old plantation. The relation of soil chemical properties with AM fungal colonization and AM fungal species composition is discussed.
\end{abstract}

Key words - AM fungal morphology - diversity - rubber tree - soil properties

\section{Introduction}

Rubber tree (Hevea brasiliensis Muell. Arg.) is one of the perennial crop species which are grown in large scale plantations in Tripura, North-East India. In Tripura, rubber plantation was introduced in 1963 to check soil degradation due to slash and burn agriculture practiced by the local tribal people. Rubber is an important cash crop in the economy of Tripura where it is cultivated in more than 40,000 ha area over hill slopes, hillocks and plains (Chaudhuri et al. 2013).

Arbuscular mycorrhizal (AM) fungi are found in 70-90\% of land plant species (Smith \& Read 2008) with fungi that belong to Glomeromycota (Schübler et al. 2001). The main benefit of mycorrhiza is its greater soil exploration and increasing uptake of $\mathrm{P}, \mathrm{N}, \mathrm{K}, \mathrm{Zn}, \mathrm{Cu}, \mathrm{S}, \mathrm{Fe}, \mathrm{Mg}, \mathrm{Ca}$ and Mn by the plants (Javot et al. 2007). AM fungal community investigation using the diversity and relative abundance of AM fungal spores has been a common practice in studies of AM fungal ecology (Oehl et al. 2005, Lovera \& Cuenca 2007). The special importance of the mycorrhizal symbiosis for the rubber tree was pointed out by different groups all over the world with respect to 
its influence on growth parameters (Ikram \& Mahmud 1984, Ikram et al. 1992, Schwob et al. 1998), use in agroforestry plant production (Feldmann \& Lieberei 1994), comparison of diversity in open land with rubber plantation (Debnath et al. 2014) and colonization by AM fungi of rubber trees in different age group of plantations was examined (Herrmann et al. 2016).

However, there is no study related to soil chemical properties and its relation with AM fungal colonization in the plantations of rubber in Tripura. Moreover, there is meager study confining to the diversity of AM fungi from the rubber plantations. In this connection, the present study is focused on the analysis of soil chemical properties, arbuscular mycorrhizal (AM) fungal colonization, AM fungal morphology in root and diversity of AM fungi in three different age groups of rubber plantations in Tripura, North-East India.

\section{Materials \& Methods}

\section{Study sites}

The samples were collected from three different rubber plantation sites of Tripura, India, i.e., 5 years old and 10 years old plantations are at Pathaliaghat and both located in the same site

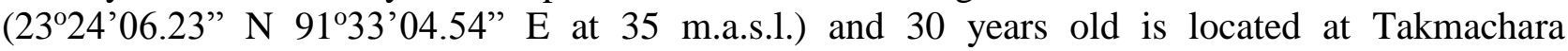
$\left(23^{\circ} 36^{\prime} 14.88^{\prime \prime} \mathrm{N} 91^{\circ} 23^{\prime} 04.32^{\prime \prime} \mathrm{E}\right.$ at 41 m.a.s.l.). The rubber plantations harbour several understorey plant communities (Debnath et al. 2014, Talapatra et al. 2015). There is no known history of using external fertilizers in these selected rubber plantations.

\section{Root and soil sampling}

The roots of five rubber trees were collected from four points around each tree from each plantation site. All the roots from each site were mixed and transferred to the laboratory for root processing and estimation of AM fungal colonization. The soil samples of approximately $500 \mathrm{~g}$ at depths of approximately $0-20 \mathrm{~cm}$ around four points of plants were mixed, labeled and zipped in polythene bags from each site. After transferring to the laboratory, the soil samples were divided into two where one fresh sample was kept for analysis of spore density and diversity. The other was then air dried in a shady place, crushed into powder form and sieved for soil properties analysis.

\section{Preparation of roots and assessment of AM fungal colonization}

The collected roots were thoroughly washed with tap water several times and cut into approximately $1 \mathrm{~cm}$ in size. Then the roots were cleaned with $10 \% \mathrm{NaOH}$ at $90^{\circ} \mathrm{C}$ for $2-3 \mathrm{~h}$, depending on the clearance of root samples. The cleared roots were washed again with tap water 4-5 times and bleached in 2 drops of alkaline $\mathrm{H}_{2} \mathrm{O}_{2}$. After acidifying with $1 \% \mathrm{HCl}$, roots were stained with Black Faber Castell stamp pad ink (Das \& Kayang 2008). After a while the roots were mounted on a slide and observed using a compound microscope for arbuscular mycorrhizal fungal structures such as arbuscules, vesicles and hyphae. The quantification of AM fungal colonization was done by the magnified intersection method (McGonigle et al. 1990).

\section{Soil analysis}

For $\mathrm{pH}$ and electrical conductivity, $10 \mathrm{~g}$ of soil was dissolved in $50 \mathrm{ml}$ of distilled water and stirred for $20 \mathrm{~min}$. This solution was kept overnight and then the soil $\mathrm{pH}$ and electrical conductivity was measured using a digital $\mathrm{pH}$ meter. The organic carbon was determined by using Walkley \& Black (1934) method. The available soil nitrogen was estimated following Black (1982) method. Available phosphorus and potassium of soil were determined using the method of Jackson (1978).

\section{Spore analysis}

Spores of AM fungi were extracted from $25 \mathrm{~g}$ of soil samples by modified wet sieving and decanting method (Muthukumar et al. 2006). The retained spores after passing through a $35 \mu \mathrm{m}$ sieve were picked up with a needle from filter paper in 1-2 drops of polyvinyl alcohollactoglycerol under a dissecting microscope (Koske \& Tessier 1983) for counting and 
identification. The identification of spores was based on morphological characteristics using descriptions provided from the websites (http://www.invam.caf.wvu.edu and http://www.Irzmuenchen.de/ schuessler/ amphylo).

\section{Data analysis}

Spore density (SD) was calculated from the number of spores in $25 \mathrm{~g}$ of soil. The correlation coefficient was employed to determine the relationships between AM fungal colonization, spore density and soil physico-chemical properties. Means were separated by Duncan test and all the statistics was performed using the software (Statistica 9.0). Species richness (SR) was calculated from the number of identified AM fungal species per soil sample. Relative abundance (RA) was measured by the following formula:

$$
\mathrm{RA}=\frac{\text { Spore numbers of a species (genus) }}{\text { Total number of identified spore samples }} \times 100
$$

Shannon-Wiener index of diversity $\left(\mathrm{H}^{\prime}\right)$ was calculated from the following formula:

$$
\mathrm{H}^{\prime}=-\sum \mathrm{Pi} \ln \mathrm{Pi}
$$

Evenness (E) was measured by the following formula:

$$
\mathrm{E}=\frac{\mathrm{H}^{\prime}}{\mathrm{H}^{\prime} \mathrm{max}}
$$

Simpson's index of dominance (D) was calculated from the following formula:

$$
\mathrm{D}=-\sum\left[\frac{\mathrm{ni}(\mathrm{ni}-1)}{\mathrm{N}(\mathrm{N}-1)}\right]
$$

Sorenson's coefficient (Cs) was measured by the following formula:

$$
\mathrm{Cs}=\frac{2 j}{(a+b)}
$$

$\mathrm{Pi}$ is the relative abundance of each identified species per sampling site and calculated by the following formula: $\mathrm{Pi}=\mathrm{ni} / \mathrm{N}$, where ni is the spore numbers of a species, and $\mathrm{N}$ is the total number of identified spore samples. $\mathrm{H}^{\prime}$ max is the maximal $\mathrm{H}^{\prime}$ and calculated by the following formula: $\mathrm{H}^{\prime}=\ln \mathrm{S}$, where $\mathrm{S}$ is the total number of identified species per sampling site. a or $\mathrm{b}$ was the total number of identified species per sampling site, and $\mathrm{j}$ was the number of identified species common to both sites (Dandan \& Zhiwei 2007).

\section{Results}

\section{Soil properties}

The chemical properties of soil showed organic carbon highest in 5 years old and lowest in 10 years old plantation, available nitrogen was also highest in 5 years old and lowest in 30 years old. The available phosphorus was high in 30 years old than 5 years old and 10 years old plantation. The 5 years old showed a lower amount of available potassium than other two sites. The soil properties are presented in Table 1. 
Table 1 Soil chemical properties of soils and spore density of AM fungi from three rubber plantations of Tripura

\begin{tabular}{lccccccc}
\hline $\begin{array}{c}\text { Age } \\
\text { (Years) }\end{array}$ & $\mathbf{p H}$ & $\begin{array}{c}\text { Electrical } \\
\text { conductivity } \\
\text { (cS cm-1) }\end{array}$ & $\begin{array}{c}\text { Organic } \\
\text { carbon } \\
\text { \% }\end{array}$ & $\begin{array}{c}\text { Available } \\
\text { nitrogen } \\
\text { (Kg/ha) }\end{array}$ & $\begin{array}{c}\text { Available } \\
\text { phosphorus } \\
\text { (Kg/ha) }\end{array}$ & $\begin{array}{c}\text { Available } \\
\text { potassium } \\
\text { (Kg/ha) }\end{array}$ & $\begin{array}{c}\text { Spore } \\
\text { density/25 } \\
\text { g soil }\end{array}$ \\
\hline 5 & 4.44 & 131 & 1.56 & 376.06 & 2.03 & 3.11 & 392 \\
10 & 4.32 & 137 & 1.19 & 366.74 & 3.66 & 320.79 & 316 \\
30 & 4.52 & 128 & 1.40 & 349.09 & 14.77 & 160.395 & 195 \\
\hline
\end{tabular}
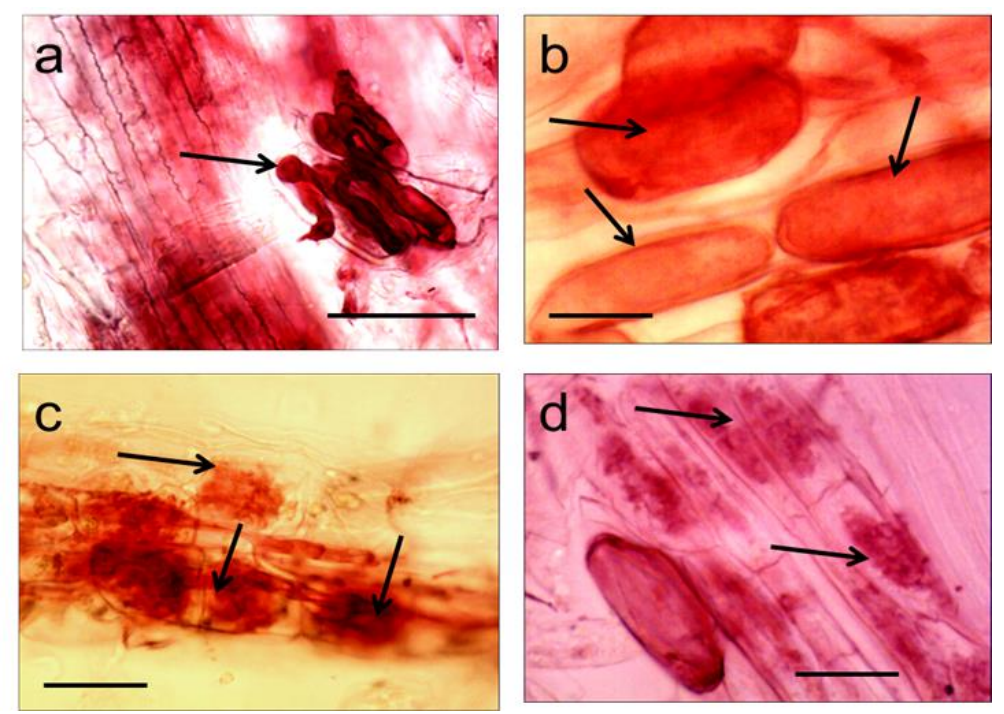

Fig 1 - Mycorrhizal colonization in Hevea brasiliensis. (a) Appressoria formation in the epidermal layer of root. (b) Vesicles. (c, d) Arbuscules exhibiting Arum type of AM morphology. Scale bars: $\mathrm{a}=200 \mu \mathrm{m}, \mathrm{b}-\mathrm{d}=100 \mu \mathrm{m}$.

\section{Mycorrhizal colonization}

The mycorrhiza-forming structures were observed in the roots of rubber plant from all the plantations. The structures such as appressoria forming in the epidermal layers, vesicles in the cortex and arbuscules in the cortex were observed (Fig. 1). The colonization of arbuscules, vesicles and hyphae were higher in the 5 years old plantation than the other two (Table 2). Arum type of AM fungal morphology was observed. The presence of intercellular fungal hyphal growth in the root cortex and development of arbuscules on intracellular hyphal branches is shown (Fig. 1c, d).

Table 2 Mycorrhizal colonization in three age groups of rubber plants

\begin{tabular}{llll}
\hline \multicolumn{1}{c}{ Age (Years) } & $\%$ Arbuscules & $\%$ Vesicles & \% Hyphae \\
\hline 5 & $13.56 \pm 1.33 \mathrm{a}$ & $21.93 \pm 1.63 \mathrm{a}$ & $59.05 \pm 1.82 \mathrm{a}$ \\
10 & $11.12 \pm 1.37 \mathrm{ab}$ & $18.61 \pm 1.92 \mathrm{ab}$ & $54.25 \pm 2.35 \mathrm{a}$ \\
30 & $8.77 \pm 1.07 \mathrm{~b}$ & $15.57 \pm 1.02 \mathrm{~b}$ & $43.99 \pm 1.77 \mathrm{~b}$ \\
\hline
\end{tabular}

Different alphabets differ significantly at $p<0.05$ 


\section{Correlation of age, soil properties and spore density of AM fungi}

The obtained data exhibited a significant positive correlation between the AM fungal colonization and spore densities with available nitrogen. There was a significant positive correlation between AM colonization with spore density. The results also describe the negative correlation between $\mathrm{pH}$ and electrical conductivity and between available potassium with organic carbon (Table 3).

\section{Distribution of AM fungal spores}

The spore density of 30 years old was lower than the other two plantation sites (Table 1). A total of 12 AM fungal morphospecies (Fig. 2) were distinguished by morphological criteria, of which 5, 9 and 9 AM fungal species were isolated from rubber plantations of 30, 5 and 10 years old plantation, respectively (Table 4). The most common genus was Glomus. It was represented by 8 species followed by Acaulospora by 2 species and Ambispora by 1 species. One morphospecies remained unidentified. G. multiculae, Glomus sp. 1, Glomus sp. 2 and Glomus sp. 3 were found in all three plantation sites. Among the isolated species, Glomus sp. 1 showed highest relative abundance. The lowest abundance in 30 years old was showed by Glomus sp. 5 , in 5 years old by 3 species i.e., Acaulospora sp. 1, Ambispora sp. 1, unidentified sp. 1 and in 10 years old plantation by Acaulospora sp. 2 and G. clavisporum.

\section{AM fungal diversity}

The diversity of AM fungi reveals Shannon-Wiener diversity index was highest in 5 years old and lowest in 30 years old. Simpson index was highest in 10 years and lowest in 5 years old plantation. Evenness was highest in 30 years old and lowest in 10 years old plantation. The diversity indices are depicted in Table 5. Sorenson coefficient of 5 and 10 years old, 5 and 30 years old, 10 and 30 years old are $0.67,0.57$ and 0.71 , respectively.

Table 3 Correlation matrix of age of rubber plantations and soil chemical properties of soils from three rubber plantations of Tripura

\begin{tabular}{lllllllllll}
\hline & Age & $\mathbf{p H}$ & $\mathbf{E C}$ & $\mathbf{O C}$ & $\mathbf{N}$ & $\mathbf{P}$ & $\mathbf{K}$ & $\mathbf{C a}$ & $\mathbf{S D}$ & $\mathbf{C o l}$ \\
\hline Age & 1.00 & 0.67 & -0.62 & -0.11 & -0.99 & $0.99^{*}$ & 0.18 & -0.78 & -0.98 & -0.99 \\
$\mathbf{p H}$ & & 1.00 & $-0.99^{*}$ & 0.66 & -0.55 & 0.73 & -0.60 & -0.99 & -0.51 & -0.58 \\
$\mathbf{E C}$ & & & 1.00 & -0.71 & 0.49 & -0.67 & 0.66 & 0.97 & 0.45 & 0.51 \\
$\mathbf{O C}$ & & & & 1.00 & 0.27 & -0.04 & $-0.99^{*}$ & -0.53 & 0.31 & 0.24 \\
$\mathbf{N}$ & & & & & 1.00 & -0.97 & -0.33 & 0.67 & $0.99^{*}$ & $0.99^{*}$ \\
$\mathbf{P}$ & & & & & & 1.00 & 0.11 & -0.82 & -0.96 & -0.98 \\
$\mathbf{K}$ & & & & & & & 1.00 & 0.47 & -0.38 & -0.31 \\
Ca & & & & & & & & 1.00 & 0.64 & 0.69 \\
SD & & & & & & & & & 1.00 & $0.99^{*}$ \\
Col & & & & & & & & & & 1.00 \\
\hline
\end{tabular}

*Correlation are significant at $p<0.05$

Age-Age (Years), EC- Electrical conductivity (cS cm-1), OC- Organic carbon \%, N- Available nitrogen (Kg/ha), PAvailable phosphorus (Kg/ha), K- Available potassium (Kg/ha), Ca- Available calcium (Kg/ha), SD- Spore density/25 g soil, Col- AM fungal colonization (\%)

\section{Discussion}

This is one of few studies of AM fungal colonization in rubber plantations and it is the first study of AM fungal morphology and comparison of AM fungal diversity in rubber plantations considering the importance of the host species worldwide.

Rubber plantations, being a closed ecosystem, recycles enormous biomass through litter decomposition which takes place rapidly thus producing considerable organic carbon in surface 
layers (Krishnakumar et al. 1991). The high contribution of organic carbon in 5 years old plantation may be due to more litter accumulation by annuals and herbaceous plant communities present in it.

There was a positive correlation between AM fungal colonization with spore density, in accord with an earlier report (Songachan et al. 2011). There is no correlation found between age and spore density. The obtained data exhibited a positive correlation between spore density with available nitrogen. Nitrogen plays an important role in influencing the mycorrhizal formation and functions mainly through changes in soil $\mathrm{pH}$ and thereby suppressing or stimulating root colonization and spore production of AM fungi (Syliva \& Neal 1990). It is assumed that under such conditions differences in spore community composition is not due to site-specific sporulation behaviour of the AM fungi but reflects the presence or absence of sporulating AM fungi at the specific site (Feldmann et al. 1995). AM fungi species composition and spore density are highly variable and influenced by plant characteristics and some environmental factors (Boddington \& Dodd 1999). Agricultural management practices, environmental conditions might affect AM fungal communities both qualitatively and quantitatively (Sieverding 1990, Miller et al. 1995).

Table 4 Relative abundance of arbuscular mycorrhizal fungi isolated from rubber plantations.

\begin{tabular}{llll}
\hline \multicolumn{1}{c}{ AM fungi } & 5 years old & 10 years old & 30 years old \\
\hline Acaulospora sp. 1 & 1.02 & 3.16 & 0.00 \\
Acaulospora sp. 2 & 0.00 & 1.05 & 0.00 \\
Ambispora sp. 1 & 1.02 & 0.00 & 0.00 \\
Glomus clavisporum & 3.06 & 1.05 & 0.00 \\
G. multiculae & 23.47 & 13.68 & 30.77 \\
G. macrocarpum & 0.00 & 3.16 & 0.00 \\
Glomus sp. 1 & 31.63 & 43.16 & 34.62 \\
Glomus sp. 2 & 22.45 & 24.21 & 14.10 \\
Glomus sp. 3 & 11.22 & 8.42 & 16.67 \\
Glomus sp. 4 & 5.10 & 0.00 & 0.00 \\
Glomus sp. 5 & 0.00 & 2.11 & 3.85 \\
Unidentified species & 1.02 & 0.00 & 0.00 \\
& 100.00 & 100.00 & 100.00 \\
\hline
\end{tabular}

Table 5 Diversity indices of AM fungi isolated from rubber plantations.

\begin{tabular}{llcc}
\hline Years & $\begin{array}{l}\text { Shannon- } \\
\text { Wiener }\end{array}$ & Evenness & Simpson's index \\
\hline 5 & 1.68 & 0.77 & 0.21 \\
10 & 1.58 & 0.72 & 0.27 \\
30 & 1.43 & 0.89 & 0.25 \\
\hline
\end{tabular}

Work on AM fungi of rubber plant of Tripura was done earlier by Deka et al. (1998) but the site of their study (Mohanpur, Agartala) was different. The results of their study showed the AM fungal spore population at horizontal, and vertical distribution from the base of the tree, and they 
isolated Glomus spp. and Gigaspora sp. In contrast, Gigaspora sp. was not found in the present study. Ikram \& Mahmud (1984) identified different spore types of Glomus sp., Acaulospora sp. and Sclerocystis coremiodes in rubber growing soils of Malaysia. Similarly, Jayaratne (1982) identified eleven species of AM fungi from rubber growing soils of Sri Lanka. The genus Glomus was highly abundant in all the plantation sites. The reports of earlier workers also revealed that Glomus is the dominant genus occurring in Indian soil (Muthukumar \& Udaiyan 2000, Bhattacharya \& Bagyaraj 2002). Das \& Kayang (2009) also reported the dominance of the Glomus from North-East region of India.
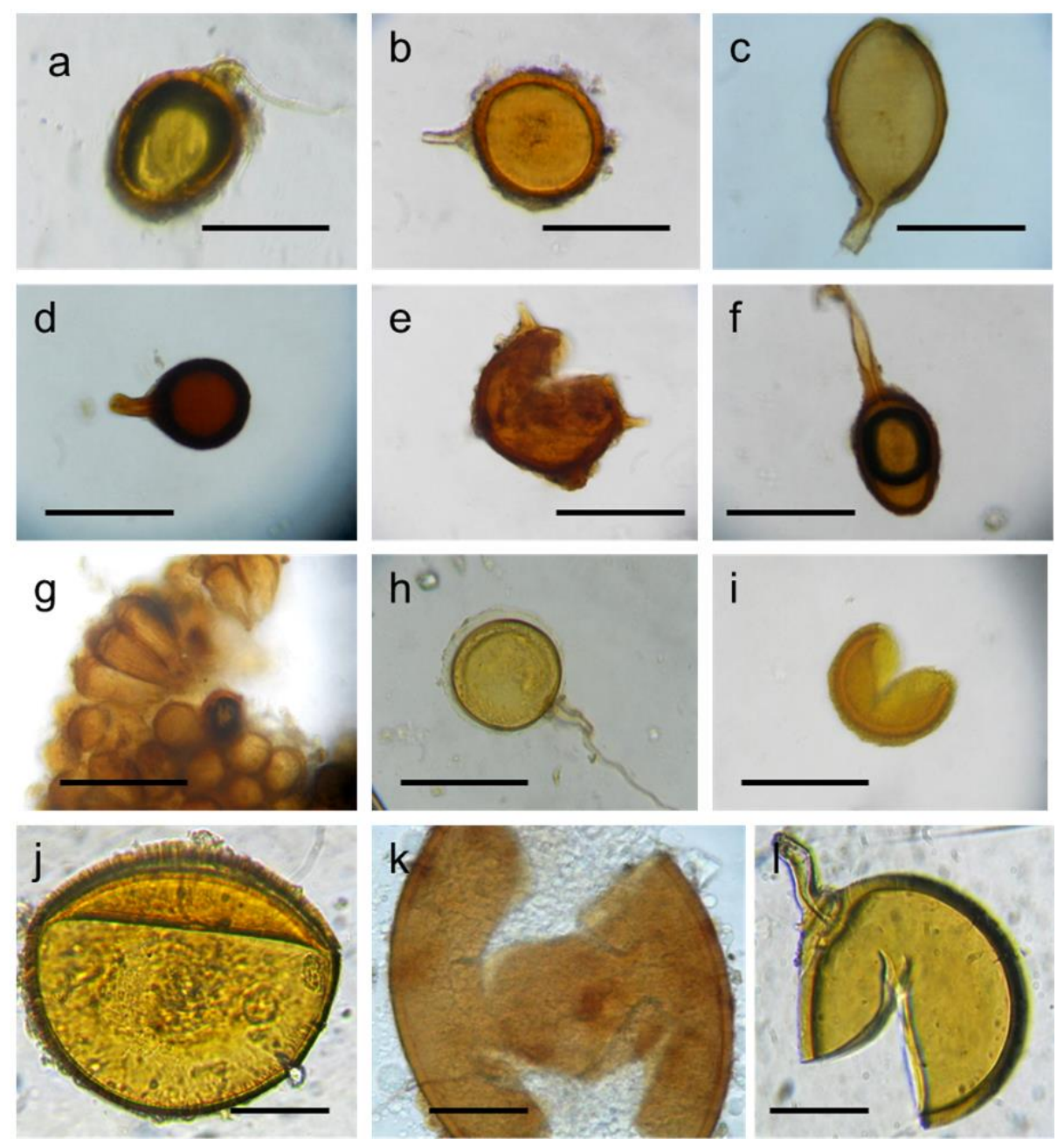

Fig 2 - Arbuscular mycorrhizal fungi isolated from rubber plantations. (a) Glomus sp. 1 (b) Glomus sp. 2 (c) Glomus sp. 3 (d) Glomus sp. 4 (e) Glomus multiculae (f) Glomus sp. 5 (g) G. clavisporum, (h) Unidentified species, (i) Ambispora sp. 1, (j) Acaulospora sp. 1, (k) Acaulospora sp. 2 and (l) Glomus macrocarpum. Scale bars: $\mathrm{a}-\mathrm{f}, \mathrm{h}, \mathrm{I}=50 \mu \mathrm{m}, \mathrm{g}, \mathrm{j}-\mathrm{l}=100 \mu \mathrm{m}$.

The diversity of AM fungi observed in the present study was slightly decreasing with the age of the rubber plantations. The diversity of AM fungi in 30 year old rubber plantation reported earlier (Debnath et al. 2014) was found to be almost similar to our findings. The diversity of AM fungi was similar in most of the coffee plantation systems (Arias et al. 2012). Helgason et al. (1998) found that woodlands had a much higher AM fungal species richness and diversity compared to agricultural land. Chifflot et al. (2009) found that AM fungal diversity was higher and spatial distribution of spores was significantly different in a tree-based intercropping site compared to a monoculture forest plantation system. Tree-based intercropping may have a positive effect on increased abundance and diversity of AM fungi (Lacombe et al. 2009, Chifflot et al. 2009). However, intercropping is not practiced in rubber plantations of Tripura. Talapatra et al. (2015) 
reported the mycorrhizal colonization of understorey plant communities in rubber plantations of Tripura. The understorey plant communities may have a role in influencing the diversity of AM fungi in the present study.

\section{Acknowledgements}

The authors are thankful to Head, Department of Botany, Tripura University for providing the laboratory facilities. The authors are grateful to the reviewer for suggestions to improve the manuscript. KC is grateful to Department of Science and Technology, Government of India for the INSPIRE fellowship.

\section{References}

Arias RM, Heredia-Abarca G, Sosa VJ, Fuentes-Ramı'rez LE. 2012 - Diversity and abundance of arbuscular mycorrhizal fungi spores under different coffee production systems and in a tropical montane cloud forest patch in Veracruz, Mexico. Agroforestry Systems 85, 179193.

Bhattacharya S, Bagyaraj DJ. 2002 - Arbuscular mycorrhizal fungi associated with Coffea arabica. Geobios 29, 93-96.

Black CA. 1982 - Methods of soil analysis. Pregmon Press, England.

Boddington CL, Dodd JC. 1999 - Evidence that differences in phosphate metabolism in mycorrhizae formed by species of Glomus and Gigaspora might be related to their life cycle strategies. New Phytologist 142, 531-538.

Chaudhuri PS, Bhattacharjee S, Dey A, Chattopadhyay S, Bhattacharya D. 2013 - Impact of age of rubber (Hevea brasiliensis) plantation on earthworm communities of West Tripura (India). Journal of Environmental Biology 34, 59-65.

Chifflot V, Rivest D, Olivier A, Cogliastro A, Khasa D. 2009 - Molecular analysis of arbuscular mycorrhizal community structure and spores distribution in tree based intercropping and forest systems. Agriculture, Ecosystems and Environment 131, 32-39.

Dandan Z, Zhiwei Z. 2007 - Biodiversity of arbuscular mycorrhizal fungi in the hot-dry valley of the Jinsha River, southwest China. Applied Soil Ecology 37, 118-128.

Das P, Kayang H. 2008 - Stamp pad ink, an effective stain for observing arbuscular mycorrhizal structure in roots. World Journal of Agricultural Science 4, 58-60.

Das P, Kayang H. 2009 - Arbuscular mycorrhizal fungi association with Blechnum orientale Linn. in pine forest and anthropogenically disturbed areas of northeast India. Archives of Agronomy and Soil Science 55, 623-632.

Debnath A, Sinha S, Saha AK, Das P. 2014 - Arbuscular mycorrhiza fungal diversity in the open land adjacent to rubber plantation in Tripura, Northeast India. Mycorrhiza News 26, 4-9.

Deka HK, Philip V, Vinod KK, Krishnakumar AK. 1998 - Spatial distribution of soil microflora in a five year old rubber plantation in Tripura. Indian Journal of Natural Rubber Research 11, 88-93.

Feldmann F, Lieberei R. 1994 - Vesicular-arbuscular mycorrhiza in rubber tree monocultures. Mycorrhiza News 5(4), 1-6.

Feldmann F, Idczak E, Martins G, Nunes J, Gasparotto L, Preisinger H, Moraes VHF, Lieberei R. 1995 - Recultivation of degraded, fallow lying areas in central Amazonia with equilibrated polycultures: response of useful plants to inoculation with VA-mycorrhizal fungi. Angewandte Botanik 69, 111-118.

Helgason T, Daniell TJ, Husband R, Fitter AH, Young JPW. 1998 - Ploughing up the wood-wide web? Nature 394, 431.

Herrmann L, Bräu L, Robin A, Robain H, Wiriyakitnateekul W, Lesueur D. 2016 - High colonization by native arbuscular mycorrhizal fungi (AMF) of rubber trees in small-holder plantations on low fertility soils in North East Thailand. Archives of Agronomy and Soil Science 62, 1041-1048. 
Ikram A, Mahmud AW. 1984 - Endomycorrhizal fungi in soils under rubber. Journal of Rubber Research Institute Malaysia 32, 198-206.

Ikram A, Mahmut AW, Ghani MN, Ibrahim MT, Zainal AB. 1992 - Field nursery inoculation of Hevea brasiliensis seedling rootstock with VAM fungi. Plant and Soil 145, 231-236.

Jackson ML. 1978 - Soil chemical analysis. Prentice Hall, New Delhi, India.

Javot H, Pumplin N, Harrison M. 2007 - Phosphate in the arbuscular mycorrhizal symbiosis: transport properties and regulatory roles. Plant Cell and Environment 30, 310-312.

Jayaratnae AHR. 1982 - Endomycorrhizas of rubber growing soils of Sri Lanka. Journal of Rubber Research Institute of Sri Lanka 60, 47-57.

Koske RE, Tessier B. 1983 - A convenient, permanent slide mounting medium. Mycological Society of America News 34, 59.

Krishnakumar AK, Gupta C, Sinha RR, Sethuraj MR, Potty SN, Eappen T, Das K. 1991 Ecological impact of rubber (Hevea brasiliensis) plantation in North East lndia. 2. Soil properties and biomass recycling. Indian Journal of Natural Rubber Research 4(2), 134141.

Lacombe S, Bradley RL, Hamel C, Beaulieu C. 2009 - Do tree-based intercropping systems increase the diversity and stability of soil microbial communities? Agriculture, Ecosystems and Environment 131, 25-31.

Lovera M, Cuenca G. 2007 - Diversidad de hongos micorrı'zicos arbusculares (HMA) y potencial micorrı'zico del suelo de una sabana natural y una sabana perturbada de la gran Sabana, Venezuela. Interciencia 3, 108-113.

McGonigle TP, Miller MH, Evans DG, Fairchild GL, Swan JA. 1990 - A new method which gives an objective measure of colonization of roots by vesicular-arbuscular mycorrhizal fungi. New Phytologist 115, 495-501.

Miller MH, McGonigle TP, Addy HD. 1995 - Functional ecology of vesicular-arbuscular mycorrhizas as influenced by phosphate fertilization and tillage in an agricultural ecosystem. Critical Reviews in Biotechnology 15, 241-255.

Muthukumar T, Udaiyan K. 2000 - Arbuscular mycorrhiza of plants growing in the Western Ghats region, Southern India. Mycorrhiza 9, 297-313.

Muthukumar T, Senthilkumar M, Rajangam M, Udaiyan K. 2006 - Arbuscular mycorrhizal morphology and dark septate fungal associations in medicinal and aromatic plants of Western Ghats, Southern India. Mycorrhiza 17, 11- 24.

Oehl F, Sieverding E, Ineichen K, Ris EA, Boller T, Wiemken A. 2005 - Community structure of arbuscular mycorrhizal fungi at different soil depths in extensively and intensively managed agroecosystems. New Phytologist 165, 273-283.

Schübler A, Schwarzott D, Walker CA. 2011 - A new fungal phylum, the Glomeromycota: phylogeny and evolution. Mycological Research 105, 1413-1421.

Schwob I, Ducher M, Sallanon H, Coudret A. 1998 - Growth and gas exchange responses of Hevea brasiliensis seedlings to inoculation with Glomus mosseae. Trees 12, 236-240.

Sieverding E. 1990 - Ecology of VAM fungi in tropical agrosystems. Agriculture, Ecosystems and Environment 29, 369-390.

Smith SE, Read DJ. 2008 - Mycorrhizal symbiosis. Academic press. London.

Songachan LS, Lyngdoh I, Highland K. 2011 - Colonization of arbuscular mycorrhizal fungi in moderately degraded sub-tropical forest stands of Meghalaya, Northeast India. Journal of Agricultural Technology 7(6), 1673-1684.

Syliva DM, Neal LH. 1990 - Nitrogen affects the phosphorous response of VA mycorrhizae. New Phytologist 115, 303-310.

Talapatra K, Das A, Roy Das A, Saha AK, Das P. 2015 - Mycorrhizal colonization of understorey plants growing in rubber plantation of Tripura in Northeast India. Mycorrhiza News 27(2), $2-8$. 
Walkley A, Black IA. 1934 - An examination of the Degtjareff method for determining organic carbon in soils: effect of variations in digestion conditions and of inorganic soil constituents. Soil Science 63, 251-263. 